\title{
Small Business Incubation and the Entrepreneurial Business Environment in South Africa: A Theoretical Perspective
}

\author{
J Dubihlela \\ Nelson Mandela Metropolitan University, Summerstrand, Port Elizabeth, South Africa \\ Email: job@vut.ac.za \\ P.J. Van Schaikwyk \\ Vaal University of Technology, Andries Portgieter Blvd, Vanderbij/park
}

Doi:10.5901/mjss.2014.v5n23p264

\begin{abstract}
Small business entreprises and entrepreneurs face numerous challenges that include lack of managerial skills, financial challenges, lack of credit, lack of access to markets, usable technology, low production, lack of interest by employees, and inadequate institutional support. The paper presents various literary perspectives on small business incubation in South Africa, the state of innovation-oriented business environment and the significance of small business incubators for developing and promoting SMEs and entrepreneurship in South Africa. Business incubators provide a good platform for the convergence mechanisms for supporting knowledge-based enterprises, both before and after their incubation. Overall, it is worth noting that business incubators do not replace entrepreneurial initiatives, but create better conditions for entrepreneurship. Furthermore, the increasing number of business incubators in South Africa shows that the right kind of business environment is increasingly being acknowledged as an important factor contributing to the success of SMEs, entrepreneurship and the local economy. Conclusions and future studies are proposed.
\end{abstract}

Keywords: Entrepreneurship; Business incubation; Small business; SMEs; South Africa;

\section{Introduction}

Small businesses face numerous challenges that include lack of managerial skills, financial challenges, lack of credit, lack of access to markets, usable technology, low production, lack of interest by employees, and inadequate institutional support (Kongolo, 2010). Small business incubation comes in as an innovative and dynamic process of enterprise development designed to accelerate the growth and success of small businesses through an array of professional and resources support and services (United Nations Economic Commission for Europe-UNECE, 1999). With small businesses increasingly becoming a major feature of economic development policy in both developed and developing countries due to their labour-absorptive capacity and their contribution to poverty alleviation and employment creation (King \& McGrath, 1999), business incubation is now regarded as dynamic hybridised economic development facilities that combine features of entrepreneurship, business facilitation and business support mechanisms (Rice \& Matthews, 1995) for economic growth world-wide. As a relatively recent and innovative entrepreneurial system (Tambunan, 2008), business incubation is derived from earlier SMEs support programmes; bearing its own distinctive characteristics stated by the United Nations Industrial Development Organization (UNIDO, 1997). In other words, incubators are recognised as inventive instruments that are increasingly becoming important in developing economies (Hanadi \& Busler, 2010), fostering the promotion of competitive small to medium enterprises (SMEs). The development and sustainability of SMEs is of critical importance for both developing and developed economies (Hanadi \& Busler, 2010).

The value and importance of SMEs lies in their significant contribution to economic development, to production, competitiveness, employment creation, industrial growth, organisational decentralisation (Hackett \& Dilts, 2004) and to social coherence (Kongolo, 2010). SMEs function as the source of new enterprises, new innovative products, dynamic applications and flexible business forms (Tambunan, 2011). In the process, they help meet the socio-economic needs; and form the zoning plans for the distribution of employment and income within the economy (Hackett \& Dilts, 2004) thereby increase the citizenry spending power and propping economic growth (Dubihlela \& Dhurup, 2013). SMEs add to the variety of goods and service offerings for customers to choose from, some of which may not be provided by the large businesses (Jackson, 2004). SMEs also act as a catalyst for economic growth as well as the development of diverse industries such as the arts, human resources, education and sport (Cronje, Du Toit \& Motlatla, 2004). At household level, 
South Africa's SMEs are acknowledged as having a significant role to play in achieving a variety of objectives such as poverty alleviation, employment creation, increased incomes, economic growth, and economic empowerment (Ghobakhloo, Arias-aranda \& Benitez-amado, 2011).

For this purpose, this paper explores literature on small business incubation in South Africa, the state of innovation-oriented business environment and the significance of small business incubators for developing and promoting SMEs and entrepreneurship in South Africa. The South African small businesses have a wide choice of business incubators to choose from in their endeavours to become successful. Government, the business sector and universities invest heavily in the establishment of business incubators (Tambunan, 2008). Many of the existing initiatives are also non-commercial and aimed at rendering a service to industry.

\section{Brief History of Business Incubation}

Over the past 55 years, small business incubators have evolved in various forms (Hackett \& Dilts, 2004). The first form of incubation was established as early as in 1959 in the United States of America (USA); although it was not called a business incubator (Wiggins \& Gibson, 2003). It consisted of the subdivision of the old Massey-Ferguson manufacturing plant in New York's Batavia, purchased by Joe Manuscoto and rented out to different kinds of small businesses (Nattrass, 2011). Nearly 25 years later, there were twelve business incubators established in the same format and operating in the same manner in USA. The United Kingdom (UK) was soon to follow and adopt the same small business nurturing strategy as the USA starting in the early 1970s. Ten years later in the early 1990s, China had about 85 small business incubators actively operating (Ndabeni, 2008).

South Africa only came on board in 1995 when the first form of a business incubator was developed by the Small Business Development Corporation (SBDC) to facilitate small business development in townships and contribute to SMEs sector growth (Buys \& Mbewana, 2007). In the townships, these forms of business incubators were known as 'hives of industry', with the necessary infrastructure like telephones, electricity, office space and warehousing space (Kongolo, 2010). These early forms of incubators were mainly focused on new technologies, light manufacturing industries and services. However, because of the high adaptability of small business incubators (Tambunan, 2011), they are now found in all industry types, and were proving to be the future of innovation-oriented business ventures and entrepreneurship (Ndabeni, 2008).

Incubators come either as government financed entities or private entities financed by large corporates or civic society. Wiggins and Gibson (2003) identify them as non-profit making operations supported by local governments, academic institutions or institutions of higher learning. According to Buys and Mbewana (2007), business incubators in South Africa were initiatives mainly launched by the departments of Trade and Industry (DTI) and Science and Technology (DST) with the objectives of creating new businesses and new employment opportunities. It was through these departments that the Godisa incubators were established; the first success story of fiscal interventions to business incubation in South Africa, with twelve operational infrastructures operational as of year 2005.

\section{Current State of Incubators in South Africa}

The small business sector in South Africa has got the best chance to create employment and improve the unemployment situation in the country (Various) where sixty there percent of small businesses fail in the first two years (businesslive.co.za). In South Africa, the incubation process is a recent phenomenon and is still evolving. Nevertheless, the limited literature in South Africa provides important insights into the nature and workings of business incubators in the country. This section identifies some key elements of the business incubation movement in South Africa and highlights some insights from the available literature. Statistics also show that the majority of businesses who were assisted by business incubators during the initial phases have a better chance to become sustainable (Ghobakhloo et al., 2011). According to Ensor (2013), incubation have been identified as a way of nurturing small businesses and linking them to more established enterprises. Further, Ensor (2013) states that thirty new applications for incubators were approved between January and September 2013 intending for 19646 jobs to be created during the ensuing 2014.

Universities also establish incubators to assist in the development of small businesses. According to Shalaby (2007), it is acknowledged that a nation's standard of living depends on the development of science and technology and that universities play a crucial role in the dissemination of scientific and technical knowledge. Research further postulates that the existing interaction between universities and business incubators has opened up new jobs through new enterprises that have been established and also through the development of existing enterprises (Robson, Helen \& Obeng, 2008). 
Table 1.1 University-based Business Incubators

\begin{tabular}{|l|l|l|}
\hline Universities of Technology & Focus Area & Province \\
\hline Durban University of Technology & Food services and hospitality management & KwaZulu Natal \\
\hline Cape Peninsula University of Technology & Clothing and textiles technology & Western Cape \\
\hline Nelson Mandela Metropolitan University & Automotive components & Eastern Cape \\
\hline Vaal University of Technology & Composite materials, non-distructive metals & Gauteng \\
\hline Mangosuthu University of Technology & Chemistry and chemical engineering & KwaZulu-Natal \\
\hline Twshane University of Technology & Automotive & Gauteng \\
\hline Conventional Universities & & \\
\hline University of the Free State & Various & Free State \\
\hline University of Pretoria & Various & Gauteng \\
\hline Stellenbosch university & Various & Western Cape \\
\hline University of Cape Town (UCT) & Various & Western Cape \\
\hline University of Johannesburg & Various & Gauteng \\
\hline Northwest University & Various & North West \\
\hline University of Kwazulu Natal & Various & Kwazulu-Natal \\
\hline
\end{tabular}

\section{Source: Adapted from Ndabeni (2008:43)}

Over and above the business incubators established by the various universities, the Department of Trade and Industry (DTI) launched the incubation programme late in 2011, from which fourteen applications were approved in 2012. By the end of 2013 a further sixteen applications were approved with nearly 20000 jobs expected to be created by these small business incubators. Most the approvals have been in the manufacturing and agricultural fields sponsored by such large corporates as Lonmin, Eskom and Transnet. These have agreed to form a partnership with the DTI to sponsor a number of other incubators that were initiated by the government institutions (Abor \& Quartey, 2010).

Private initiatives such as The Business Place initiated and funded by Investec (Ghobakhloo et al., 2011) are based on a Canadian model of local company development. Each branch is a private-public partnership but is not a supplier of funds. Sometimes people with good ideas are put into touch with other more suitable incubators like the ChemCity business incubator, part of the Sasol group - a multi-sectoral facility - in Sasolburg in 2013 (Ensor, 2013). Pick-n-Pay also assists small emerging companies through their Small Business Incubator (Makhaya, 2014).

Table 1.2 Industry-based Business Incubators

\begin{tabular}{|c|c|c|}
\hline Name of Incubator & Incubator Focus Area & \begin{tabular}{|l} 
Provincial Location \\
\end{tabular} \\
\hline Godisa Incubators (DST, DTI and EU initiative) & $\begin{array}{l}\text { Independent trust, incubator centres that just support and offer advisory } \\
\text { services }\end{array}$ & Various (12) - SA \\
\hline Acorn Incubator & Life science technologies and small enterprise development & Western Cape \\
\hline Brainworks Technology Incubator & ICT and Electronics; supports high-tech start-ups & Gauteng \\
\hline eGoli Biotechnology Incubator & Life sciences research, products, services and technology platforms & Gauteng \\
\hline SA Chemical Technology Incubator & Supports downstream chemical manufacturing SMMEs & Eastern Cape \\
\hline Timbhale Incubator & Export-based cut flower and nutriceuticals & Mpumalanga \\
\hline The Innovation Hub & Start-ups companies at the leading edge of new technology economy & Various (9) - SA \\
\hline KwaZulu-Natal Innovation Support Centre & Technology commercialisation, skills development & KwaZulu-Natal \\
\hline Zenzele Technology Demonstration Centre & Small-scale mining and agricultural initiatives & Gauteng \\
\hline The Business Place (Investec) & Small, micro and medium enterprise development & Gauteng \\
\hline Patel & Training to unemployed accounting graduates & Gauteng \\
\hline PicknPay Small Business Incubator (SBI) & Assists emerging companies and SMEs & Westerb Cape \\
\hline African Rose Enterprise Development & Support to oil farmers and agro-processing & KwaZulu Natal \\
\hline Aurik Business Accelerator & Invests in entrepreneurs and builds small businesses & Various - SA \\
\hline Chemin & Support SME's in the downstream chemical industry & Eastern Cape \\
\hline Endeavour & Assist high-growth entrepreneurs in emerging markets & International \\
\hline $\begin{array}{l}\text { The Downstream Aluminium Centre for } \\
\text { Technology }\end{array}$ & Incubation of small aluminium casting enterprises & KwaZulu-Natal \\
\hline Egoli Bio & Assist entrepreneurial life sciences and biotechnology ventures & Gauteng \\
\hline Furntech & Assist SMME's involved in furniture manufacture & Gauteng \\
\hline Shanduka Black Umbrellas & Support emerging black entrepreneurs and small businesses & Various - SA \\
\hline Mpumalanga agri-skills & Promotes sustainable agricultural empowerment & Mpumalanga \\
\hline Mpumalanga Stainless Initiative (MSI) & Works with SME's in the manufacturing sector & Mpumalanga \\
\hline The Nelson Mandela Bay Incubator & Contribute in the process of creating successful small ICT enterprises. & Eastern Cape \\
\hline
\end{tabular}




\begin{tabular}{|l|l|l|}
\hline Raizecorp's Business Incubator & Provide full-service business support programmes to guide entrepreneurs & Various - SA \\
\hline Seda(DTI) (Various initiatives) & Develop, support and promote small enterprises & Various - SA \\
\hline Soft-Start Business and Technology Incubator & Real estate entrepreneurship start-up and growth & Western Cape \\
\hline $\begin{array}{l}\text { Soshanguwe manufacturing technology } \\
\text { demonstration centre }\end{array}$ & Small-scale manufacturing machinery and equipment for entrepreneurs & Gauteng \\
\hline Timbali Technology Incubator & Support emerging farmers in the cut flower market & Gauteng \\
\hline Gauteng Software Incubator & Software technology development and small business & Gauteng \\
\hline ChemCity & Support small business growth in chemical technology & Various - SA \\
\hline Eskom & Enterprise technology development and capacity building & Various - SA \\
\hline
\end{tabular}

Source: Author compilation from various publications

\section{Significance of Business Incubators in South Africa}

In South Africa, the most advanced business incubator is the Innovation Hub, which focuses on high-technology entrepreneurs and start-up companies at the leading edge of the new economy (Buys \& Mbewana, 2007). The Gauteng Provincial Government, through the Blue IQ initiative, announced in 2000 that the Innovation Hub would be developed as one of the major projects to stimulate economic growth in the province (Makhaya, 2014). The initiative was launched in February 2000 and the Innovation Hub started operating in December 2000. It is the first internationally accredited science park in Africa, a high-tech cluster that creates an environment where international businesses can access a regional centre of knowledge creation (International Labour Organization, 2000). Overall, it builds on best practice to create the essence of a science park while providing a gateway for local businesses to launch into the world of global interconnectivity successfully (Abor \& Quartey, 2010). Further, the cooperation between industry and educational institutions enables universities to move from basic to applied research (Giesecke, 1999). Overall, the collaborative efforts between government, research institutions and universities of technology are encouraging. In particular, collaborative relationships are expected to promote economic development, job creation, technology transfer and innovation.

Overall, the increasing number of business incubators in South Africa shows that the right kind of business environment is increasingly being acknowledged as an important factor contributing to the success of SMMEs and the local economy. Likewise, the number of technology stations is evidence of the importance of know-how and technology transfer between the universities and SMMEs (Besser, 1996). In sum, these business development instruments are proving to be cost-effective ways of helping to start technology-based enterprises.

\section{Potential Benefits of Incubation}

Eleven potential success factors were identified for business incubators. In an analysis done a very strong correlation was found between incubator success and a conducive environment and a very weak relationship between incubator success and a proper business plan, stringent selection criteria and an experienced advisory board.

Eleven potential success factors for business incubators.

\begin{tabular}{|c|l|}
\hline \multicolumn{2}{|l|}{ The set of eleven potential success factors for business incubation } \\
\hline 1 & Access to science and technology expertise and facilities \\
\hline 2 & Comprehensive business plan \\
\hline 3 & Stringent selection criteria \\
\hline 4 & Available funding \\
\hline 5 & Quality of entrepreneurs \\
\hline 6 & Stakeholder support \\
\hline 7 & Supportive government policies \\
\hline 8 & Competitive and motivated management \\
\hline 9 & Financial sustainability \\
\hline 10 & Experienced advisory board \\
\hline 11 & Networking. \\
\hline
\end{tabular}

Source: Buys \& Mbewana (2007:13)

Incubators in South Africa are established by Government, the private sector, higher education institutions and overseas initiatives such as the Branson Centre of Entrepreneurship (South Africa) that have taken hands with Nedbank to form a partnership to fund its local involvement with the small business sector (Nattrass, 2011). Unlike many business 
assistance programs, business incubators do not serve all companies; instead, entrepreneurs who wish to enter a business incubation program must apply for admission. Acceptable criteria vary from program to program, but in general only those with feasible business ideas and a workable business plan are admitted (Hanadi \& Busler, 2010). It is this factor that makes it difficult to compare the success rates of incubated companies against general business survival statistics (Buys \& Mbewana, 2007).

More than half of incubation programs surveyed in 2006 by the National Business Incubation Association reported that they served as affiliates or virtual clients of other corporations. These companies do not reside in the incubator facility. Affiliate clients may be home-based businesses or early-stage companies that have their own premises but can benefit from incubator services offered by large corporations (Olawale \& Garwe, 2010). Virtual clients may be too remote from an incubation facility to participate on site, and so receive counselling and other assistance electronically.

\section{Some Models of Business Incubation}

Their key objectives are economic growth, sustainable employment, technological innovation and technology transfer, and making South African SMMEs internationally competitive. The technology stations' activities include, inter alia, research, development and application of new technologies, technology transfer, troubleshooting, quality advisory service, product development, simulated production units, testing services and secondment of staff and students (Business Referral \& Information Network, 2004).

\section{Conclusions}

The future growth of a modern small-business sector requires renewed efforts to improve production methods, to raise quality and to shift to value-added products and services through modern design and technological innovations. It also requires a special focus on support systems that provide integrated services for production, management, marketing and finance (International Labour Organization, 2008). The business incubators provide a good platform for the convergence mechanisms for supporting knowledge-based enterprises, both before and after their incubation (Olawale \& Garwe, 2010). Incubator assessments carried out by the United Nations Development Programme in Brazil, the Czech Republic, the People's Republic of China, Mexico, Nigeria, Poland and Turkey point to the potential of incubators for creating innovative enterprises, greatly increasing their chances of survival and success, generating jobs directly while firms are still within the incubator and even larger employment when they graduate and grow, and at the same time promoting the commercialisation of research, fostering skills for entrepreneurship and influencing national policies for small enterprise development (UNIDO, 1997).

Finally, links between business incubators and universities are important. Incubators provide a proven economic development tool for their communities. In the last four decades, incubated companies are estimated to have created more than 0.25 million jobs (Wiggins \& Gibson, 2003), which potentially increased the tax base. The incubators operations have occupied additional commercial real estate space, contributed to the local business infrastructure, and lead to additional job creation in various business sectors (Buys \& Mbewana, 2007). Likewise, the United Nations Industrial Development Organization (1997) states that the involvement of private-sector corporations has grown over the years and has significantly boosts small business incubation and SMEs development. Overall, it is worth noting that business incubators do not replace entrepreneurial initiatives, but create better conditions for entrepreneurship.

\section{References}

Abor, J \& Quartey, P. (2010). Issues in SME Development in Ghana and South Africa. International Research Journal of Finance and Economics, 39,1: 218-228.

Australia \& New Zealand Association of Business Incubators. (2003). Business incubation. http://www.anzabi.com.au/dispaly/text, Accessed 11August 2014.

Besser, T. L. (1996). Growing jobs in business incubators. http://www.extension.iastate.edu/communities/news/ComCon38.html, Accessed 9 August 2014.

Burns, J. (2001). Introduction to the Godisa programme. Unpublished correspondence, Department of Science and Technology, Pretoria.

Business Referral \& Information Network. (2004). Technology stations program, incubators and science parks. http.//www.brain.org.za/ Support/Technostations.html, Accessed 23 June 2014.

Buys, A.J. \& Mbewana, P.N. (2007). Key success factors for business incubation in South Africa: the Godisa case study. South African Journal of Science (103): 357-358.

Campbell, C. \& Allen, D.A. (1987). The small business incubator industry: Microlevel economic development. Economic Development Quarterly, 1(2): 178-91. 
Cronje, G.J.de J, Du Toit, G.S \& Motlatla, M.D.C. (2004). Introduction to business management. Sixth edition. Cape Town: Oxford Business Press. Department of Trade \& Industry. (1998). Rural SMME strategy. Pretoria: Government Printer.

Dubihlela, J. \& Dhurup, M. (2013). A factorial analysis of the barriers to market orientation adoption among Small and Medium Enterprises (SMEs) in a developing country. International Business \& Economics Research Journal (IBER), 12, (11):1331-1333.

Edelman, M. (1997). Can rural communities be business incubators? Www.extension.istate.edu/communities/news, Accessed 9 August 2014.

Ensor, L. (2013). Big business lags on empowerment, says Davies. Business Day -Live. http://www.bdlive.co.za/business/2013/10/17/ bigbusiness-lags-on-empowerment-says-davies. Accessed 5 August 2014

Ghobakhloo, M., Arias-aranda, D. \& Benitez-amado, J. (2011). Adoption of e-commerce applications in SMEs. Journal of Industrial Management Data Systems, 111(8), 1238-1269.

Giesecke, S. (1999). Determinants of successful S\&T policy in a national system of innovation. Proceedings of the 3rd International Conference on Technology Policy and Innovation: Assessment, Commercialization and Application of Science and Technology and the Management of Knowledge, 30 August-2 September, University of Texas, Austin, USA.

Godisa. (2004). Introduction to the Godisa programme. http://www.godisa.net, Accessed 23 June 2014.

Hackett, S.M. \& Dilts, D.M. (2004). A systematic review of business incubation research. The Journal of Technology Transfer, 29, 1, 55-82.

Hanadi, M. A. M. \& Busler, M. (2010). Business Incubators: Findings from a Worldwide Survey, and Guidance for the GCC States. Global Business Review, 11, 1, 23-29

International Labour Organization. (2000). Case study: regional development agencies, business centers and business incubators in Bulgaria from 1995-1999. Geneva: ILO.

International Labour Organization. (2008). Government support to SMEs in Lithuania.http://www.logos-net/ilo/150_base/en/init/lit_2.htm. Accessed 20 May 2014.

Innovation Hub. (2006). The innovation hub business incubator. http:// www.innovationhub.co.za/incubator.cfm, Accessed 20 May 2014.

King, K. (1996). Jua Kali Kenya: Change and development in an informal economy 1970-1995. London: James Currey.

King, K. \& Mcgrath, S. (Eds). (1999). Enterprise in Africa: between poverty and growth. London: Intermediate Publications.

Kongolo, M. (2010). Job creation versus job shedding and the role of SMEs in economicdevelopment. African Journal of Business Management, 4, 11, 2288-2295

Kumar, U. \& Kumar, V. (1997). Incubating technology: Best practices. http:// www.nrc.calfptt/kumar.html, Accessed 11 August 2014.

Lalkaka, R. (2013). Venture creation and growth through business incubators and technology parks. http://techpark.ir/Parks/ English/Articles/Lalkaka3.htm, Accessed 19 August 2014.

Makhaya, T. (2014). Let us also look at constraints from dominant firms. Business Day -Live. http://www.bdlive.co.za/ business/2014/08/05. Accessed 5 August 2014

Marsden, K. (1992). African entrepreneurs: Pioneers of development. Small Enterprise Development, 3: 15-25.

Nattrass, N. (2011). The new growth path: Game changing vision or cop-out? South African Journal of Science, 107(3/4): 638-647

Ndabeni, L. L. (2008). The contribution of business incubators and technology stations to Small Enterprise development in South Africa. Development Southern Africa (25:3), 263.

Olawale, F \& Garwe, D. (2010). Obstacles to the growth of new SMEs in South Africa: Aprincipal component analysis approach. African Journal of Business Management, 4, 5: 729-738

Philip, K. (2001). The quest for rural enterprise support strategies that work: a case study of Mineworkers

Development Agency. Proceedings of the Conference on the Role of Adult Education in Sustainable Development, 27-29 November, Johannesburg, South Africa.

Rice, M.P. \& Matthews, J.B. (1995). Growing new ventures, creating new jobs: principles and practices of successful incubation. London: Quorum Books.

Richards, S. (2002). Inside business incubators and corporate ventures. New York: John Wiley \& Sons.

Robson, P. J. A., Helen M. H., Obeng, B. A. (2008). Entrepreneurship and innovation in Ghana: Enterprising Africa. Small Business Economy, 32, 346.

Shalaby, N. (2007). Enhancing incubator performance towards sustainability. Economic Focus, 2. (2):48-53, summer 2007

Steel, W. F. (1994). Changing the institutional and policy environment for small enterprise development in Africa. Small Enterprise Development, 5: 4-9.

Tambunan, T. T. H. (2008). SME development, economic growth, and government intervention in a developing country: The Indonesian story. Journal of International Entrepreneurship, 6, (4): 147-67.

Tambunan, T.T.H. (2011). Overview of Financial Framework for Supporting MSMEs in Indonesia. PPT presented at The Third Country Training Programme on Micro Finance for African Region: Managing Micro Finance Institution, the Non-Aligned Movement Centre for South-South Technical Cooperation (NAM CSSTC) and the Japan International Cooperation Agency (JICA), 11 October 2011, Jakarta: NAM Centre Building.

United Nations Economic Commission for Europe. (1999). Promoting and sustaining business incubators for the development of SMEs. Discussion paper prepared for the expert meeting on best practices in business incubation, UNECE, Geneva.

United Nations Industrial Development Organization. (1997). Lessons from international experience for the promotion of business incubation systems in emerging economies. Paper commissioned by the Small and Medium Industries Branch, UNIDO, New York.

Wiggins, J. \& Gibson, D.V. (2003). Overview of US incubators and the case of the Austin Technology Incubator. International Journal of Entrepreneurship and Innovation Management, 3, (1/2): 56-67 